\title{
THE INFLUENCES OF HYDROLOGY ON THE RADIOGENIC AND STABLE CARBON ISOTOPE COMPOSITION OF CAVE DRIP WATER, GROTTA DI ERNESTO (ITALY)
}

\author{
J Fohlmeister ${ }^{1,2} \bullet$ A Schröder-Ritzrau ${ }^{1} \cdot \mathrm{C} \mathrm{Spötl}^{3} \bullet \mathrm{S} \mathrm{Frisia}^{4} \bullet \mathrm{R}_{\text {Miorandi }}^{5} \bullet$ B Kromer $^{1} \bullet$ \\ A Mangini ${ }^{1}$
}

\begin{abstract}
C}$ and $\delta^{13} \mathrm{C}$ values of $\mathrm{C}$-containing species in cave drip waters are mainly controlled by the $\mathrm{C}$ isotope composition of karst rock and soil air, as well as by soil carbon dynamics, in particular the amount of soil $\mathrm{CO}_{2}$ in the unsaturated soil zone and the process of calcite dissolution. Here, we investigate soil carbon dynamics by analyzing the ${ }^{14} \mathrm{C}$ activity and $\delta^{13} \mathrm{C}$ values of $\mathrm{C}$ dissolved in cave drip water. Monthly over a 2-yr period, we collected drip water from 2 drip sites, one fast and one relatively slow, within the shallow Grotta di Ernesto Cave (NE Italy). The ${ }^{14} \mathrm{C}$ data reveal a pronounced annual cycle. In contrast, the $\delta^{13} \mathrm{C}$ values do not show an annual pattern and only small interannual variability compared to the $\delta^{13} \mathrm{C}$ values of soil waters. The annual ${ }^{14} \mathrm{C}$ drip-water cycle is a function of drip-rate variability, soil moisture, and ultimately hydrology.
\end{abstract}

\section{INTRODUCTION}

Radiocarbon techniques are successfully used to determine the age of groundwater in karst systems by measuring the ${ }^{14} \mathrm{C}$ activity of the dissolved inorganic carbon (DIC) (Clark and Fritz 1997). Despite the usefulness of ${ }^{14} \mathrm{C}$ to estimate age and residence time of karst waters, which play a central role in water resource sustainability, the proportion to which carbonate bedrock dilutes the ${ }^{14} \mathrm{C}$ signal of $\mathrm{CO}_{2}$ evolved from organic matter decay in the soil zone is still a matter of debate (Criss et al. 2007). ${ }^{14} \mathrm{C}$ activity in the recent portion of secondary mineral deposits formed in caves, known as speleothems, is commonly used to identify the ${ }^{14} \mathrm{C}$ peak related to the increased atmospheric load during the 1960s related to nuclear tests (Genty and Massault 1997). Therefore, a prerequisite for karst water and speleothem ${ }^{14} \mathrm{C}$ dating is identifying the extent of water-rock interaction. A deeper understanding of the extent of reaction with the host rock can be obtained by coupling ${ }^{14} \mathrm{C}$ and $\delta^{13} \mathrm{C}$ measurements (Criss et al. 2007), which is the focus of the present study.

The initial ${ }^{14} \mathrm{C}$ activity of speleothems and speleothem drip water is controlled by a mixture of 2 end members, the ${ }^{14} \mathrm{C}$ content of soil $\mathrm{CO}_{2}$, typically close to the atmospheric ${ }^{14} \mathrm{C}$ level, and the $\mathrm{C}$ originating from dissolution of the carbonate host rock, commonly devoid of ${ }^{14} \mathrm{C}$. The activity ratio of the first end member is modified by the dissolution of gaseous $\mathrm{CO}_{2}$ in soil water. Additionally, the ${ }^{14} \mathrm{C}$ activity of the acidic solution depends on the soil air ${ }^{14} \mathrm{C}$ activity, the partial pressure of soil $\mathrm{CO}_{2}$ $\left(\mathrm{pCO}_{2}\right)$, and temperature-dependent isotope fractionation factors (Garrels and Christ 1965; Hendy 1971; Salomons and Mook 1986; Dulinski and Rozanski 1990).

Soil air carbon dioxide $\left(\mathrm{CO}_{2, \mathrm{~g}}\right)$ is composed of $\mathrm{CO}_{2}$ from root respiration and microbial decomposition of dead organic matter. Root respiration introduces modern ${ }^{14} \mathrm{C}$ values to the total $\mathrm{CO}_{2, \mathrm{~g}}$, whereas microbial decomposition of soil organic matter (SOM) introduces $\mathrm{CO}_{2}$ that has the composition of past atmospheric ${ }^{14} \mathrm{C}$ activities less the small amount of ${ }^{14} \mathrm{C}$ decayed since the time the dead $\mathrm{OM}$ was buried within the soil. The proportion of both components to the total soil $\mathrm{CO}_{2}$ varies interannually (Dörr and Münnich 1986). During periods with less ${ }^{14} \mathrm{C}$ change in the atmosphere, and due to the relatively short turnover time of SOM (e.g. Trumbore 2000), $\mathrm{CO}_{2}$ derived by decomposition of SOM has near-atmospheric ${ }^{14} \mathrm{C}$ values. As a result, the total soil air ${ }^{14} \mathrm{C}$ activity approximates atmospheric ${ }^{14} \mathrm{C}$ values, except for periods with fast and significant atmospheric ${ }^{14} \mathrm{C}$ variations. The

\footnotetext{
${ }^{1}$ Heidelberger Akademie der Wissenschaften, Im Neuenheimer Feld 229, Heidelberg 69120, Germany.

${ }^{2}$ Corresponding author. Email: jens.fohlmeister@iup.uni-heidelberg.de.

${ }^{3}$ Institut für Geologie und Paläontologie, Leopold-Franzens-Universität, Innrain 52, Innsbruck 6020, Austria.

${ }^{4}$ School of Environmental and Life Sciences, University of Newcastle, Callaghan 2308, NSW, Australia.

${ }^{5}$ Museo Tridentino di Scienze Naturali, via Calepina 14, Trento 38100, Italy.
} 
$\delta^{13} \mathrm{C}$ values of the respired $\mathrm{CO}_{2}$ derived from root respiration and decomposition of $\mathrm{SOM}$ are identical. For plants using the $\mathrm{C}_{3}$ pathway of photosynthesis, the soil air $\mathrm{CO}_{2}$ sources respire $\mathrm{CO}_{2, \mathrm{~g}}$ whose $\delta^{13} \mathrm{C}$ values are around $-25 \%$ (Deines 1980). This soil air $\mathrm{CO}_{2, \mathrm{~g}}$ then equilibrates with the soil water by converting the gaseous $\mathrm{CO}_{2, \mathrm{~g}}$ to aqueous $\mathrm{CO}_{2, \text { aq }}$, which, according to the $\mathrm{pH}$, then dissociates to bicarbonate $\left(\mathrm{HCO}_{3}{ }^{-}\right)$and finally to the carbonate ion $\mathrm{CO}_{3}{ }^{2-}$. For soil air, $\mathrm{pCO}_{2}$ values usually found in soils (McDermott 2004), and accordingly low $\mathrm{pH}$ values in the soil water (Cerling 1984 ) isotope fractionation processes between the $\mathrm{C}$-species, lead to an enrichment of the ${ }^{14} \mathrm{C}$ activities and of the $\delta^{13} \mathrm{C}$ values in the solution compared to soil air $\mathrm{CO}_{2, \mathrm{~g}}$. The strength of the enrichment is controlled by the relative distribution of DIC species in water, which in turn depends on the soil air $\mathrm{pCO}_{2}$ (Hendy 1970, 1971). For example, Hendy (1970) modeled this relationship for water saturated with respect to calcite and varied soil air $\mathrm{pCO}_{2}$ from 8100 to $125,000 \mathrm{ppm}$ and found changes in the ${ }^{14} \mathrm{C}$ activity from 49.4 to $63.5 \mathrm{pMC}$ with $\delta^{13} \mathrm{C}$ values varying between -11.5 and $-14.9 \%$. The solution saturated with carbon dioxide gas subsequently enters the karst aquifer, and carbonate rock dissolution occurs until the water is saturated with respect to calcite.

Models of isotopic exchange in karst aquifers consider in general 2 limiting cases of carbonate dissolution that occur under open and closed conditions (e.g. Wendt et al. 1967; Hendy 1970; Wigley 1975; McDermott 2004). In a closed system, the aqueous solution has no contact with the infinite soil $\mathrm{CO}_{2}$ reservoir during the dissolution process. Therefore, for each mole of carbonate ion species derived from the acid hydrolysis of the host rock, 1 mole of aqueous carbon dioxide is converted to bicarbonate. When the solution becomes saturated with respect to calcite, approximately half of the $\mathrm{C}$ atoms originate from the carbonate rock, which is devoid of ${ }^{14} \mathrm{C}$, and the other half is derived from soil air $\mathrm{CO}_{2}$ (Hendy 1971). Consequently, the apparent age of the reservoir is close to 1 half-life. In an open system, the aqueous solution keeps equilibrating with the unlimited reservoir of soil gaseous carbon dioxide during carbonate dissolution. Hence, in the open carbonate dissolution system more $\mathrm{Ca}^{2+}$ is dissolved than in the closed system. In this process, isotopic exchange between DIC and soil air $\mathrm{CO}_{2}$ is responsible for a ${ }^{14} \mathrm{C}$ activity of karst water that is similar to the values of soil air $\mathrm{CO}_{2}$. The open and closed systems are 2 "theoretical" end-member cases of carbonate dissolution in karst aquifers. In most soil-rock-cave systems, the carbonate dissolution occurs in conditions that are intermediate between completely open and completely closed systems. This intermediate system combines the characteristics of both end members with respect to the isotopic composition of the $\mathrm{C}$ species in solution. With a change to a more open (closed) carbonate dissolution system, we expect higher (lower) ${ }^{14} \mathrm{C}$ values, lower (higher) $\delta^{13} \mathrm{C}$ values, and higher (lower) $\mathrm{Ca}^{2+}$ concentrations in the saturated aquifer and cave water. In the intermediate system, the partial pressure of $\mathrm{CO}_{2}$ and the ${ }^{14} \mathrm{C}$ activity of soil $\mathrm{CO}_{2}$ in the unsaturated soil zone are the dominant factors controlling the magnitude of ${ }^{14} \mathrm{C}$ activity of the dissolved $\mathrm{C}$ species in the waters that enter a cave.

Variability in the ${ }^{14} \mathrm{C}$ activity and $\delta^{13} \mathrm{C}$ values of the DIC in cave drip waters allows us to set quantitative constraints on the processes occurring in the soil zone during carbonate dissolution and in the cave. This is due to the different behavior of radiogenic and stable $\mathrm{C}$ isotopes in soil and karst processes. On the one hand, the ${ }^{14} \mathrm{C}$ activity of soil water is depleted in ${ }^{14} \mathrm{C}$ during carbonate dissolution due to the absence of ${ }^{14} \mathrm{C}$ in the geologically old host rock. On the other hand, the strongly depleted $\delta^{13} \mathrm{C}$ value of soil-respired $\mathrm{CO}_{2}$ in equilibrium with $\mathrm{C}_{3}$-dominated vegetation coverage (about $-25 \%$ ) and $\mathrm{C}$ species in soil water is shifted towards more positive values by carbonate dissolution due to the $\delta^{13} \mathrm{C}$ value of carbonate rock, which is typically $\sim 0 \%$ for those of marine origin.

Variations in the open and closed system behavior can therefore be identified by comparing pairs of ${ }^{14} \mathrm{C}$ activity and $\delta^{13} \mathrm{C}$ values of DIC. As described above for the $\mathrm{Ca}^{2+}$ concentration, lower (higher)

${ }^{14} \mathrm{C}$ activities and higher (lower) $\delta^{13} \mathrm{C}$ values are expected in the solution, if the carbonate dissolu- 
tion occurs under more closed (open) conditions. This results in an anticorrelation between both C isotopes, which, in addition, is accompanied by important $\mathrm{Ca}^{2+}$ concentration changes. Furthermore, a negative correlation is introduced between ${ }^{14} \mathrm{C}$ and $\delta^{13} \mathrm{C}$ if $\mathrm{C}$ exchange processes between DIC of the solution and the $\mathrm{C}$ in the carbonate rock influence the $\mathrm{C}$ isotopic composition of the drip water. $\mathrm{C}$ exchange processes between the DIC of the solution and $\mathrm{CaCO}_{3}$ occur mainly when the solution is saturated with respect to calcite. During this process, the C isotope composition of the DIC is modified, due to the small proportions of back-and-forth reaction, which occur even at chemical equilibrium. In contrast to variations in the dissolution system, C isotope exchange between DIC of the solution and host-rock carbonate does not change the $\mathrm{Ca}^{2+}$ concentration in the solution. The annual vegetation cycle is responsible for more depleted $\delta^{13} \mathrm{C}$ values and higher ${ }^{14} \mathrm{C}$ activities (Dörr and Münnich 1986) in spring and summer and for higher $\delta^{13} \mathrm{C}$ values and lower ${ }^{14} \mathrm{C}$ activities in autumn and winter. This leads to an anticorrelation, but with a different slope between ${ }^{14} \mathrm{C}$ and $\delta^{13} \mathrm{C}$ compared to the first processes. A positive correlation is generated by the isotopic fractionation between the participating $\mathrm{C}$ species because the radiogenic and the stable $\mathrm{C}$ isotopes have the same fractionation characteristics despite the fact that the fractionation for ${ }^{14} \mathrm{C}$ is twice as high as for $\delta^{13} \mathrm{C}$.

In the present study, $\mathrm{C}$ isotopes in a well-monitored mid-altitude alpine karst system are investigated to gain information on the present-day processes that influence isotopic exchange in soils of mountain regions. The ultimate goal is a better understanding of the environmental significance of the variability of $\mathrm{C}$ isotope values over time in speleothems, which have been, so far, interpreted in terms of vegetation changes or generic "soil processes." In particular, the aim of this study is to quantify the different processes that control annual variations in the C isotope content of DIC in cave drip waters by using a multiproxy approach coupled with monitoring studies.

\section{CAVE LOCATION AND SAMPLE PREPARATION}

\section{Study Site}

Grotta di Ernesto is a shallow cave located $1167 \mathrm{~m}$ asl on the northern, steep slope of Valsugana Valley (Trentino Province) in northeast Italy. It is overlain by $5-30 \mathrm{~m}$ of dolomitic limestone. This cave is ideally suited for this study because it is small, largely undisturbed, and one of the most extensively monitored cave sites worldwide (e.g. Borsato 1997; McDermott et al. 1999; Huang et al. 2001; Frisia et al. 2003; Borsato et al. 2007). The vegetation above the cave consists entirely of $\mathrm{C}_{3}$ plants in a mixed forest association, with predominant Picea abies and subordinate Fagus sylvatica, plus seasonal shrubs and grass. The soil is typical of a mixed forest in the upper mountain zone with parent material mostly consisting of limestone debris, namely Calcari-mollic Cambisol according to the World Reference Base for Soil Resources 1998 (Merkli et al. 2009). In the subsurface, the 70-mlong cave passage has a temperature of $\sim 6.6^{\circ} \mathrm{C}$ all year round, which reflects the mean annual air temperature at the surface. The average mean annual precipitation measured at the nearby meteorological station Vezzena (30-yr mean) is $\sim 1300 \mathrm{~mm}$ and shows bimodal distribution with maxima during spring and autumn. Taking into account evapotranspiration (calculated after Thornthwaite 1948), the highest soil infiltration occurs in autumn. Snow is usually present in the winter months and melts during March and April, resulting in an important infiltration event. The karst aquifer reservoir, which feeds the drips in the cave beneath, is well equilibrated with a mean annual soil air $\mathrm{pCO}_{2}$ (Fairchild et al. 2000; Frisia et al. 2005).

Water samples from 2 cave drip sites were analyzed for their $\mathrm{C}$ isotopic composition. One of the sites, ER-G1, has a fast dripping seasonal drip, whereas the second drip site, ER-76, has a slow dripping seasonal drip. Their typical discharge is $5-10 \mathrm{~mL} / \mathrm{min}$ and $0.1-0.5 \mathrm{~mL} / \mathrm{min}$, respectively. The drip rate was measured manually once a month. ER-G1 drip rates are delayed relative to precipita- 
tion events by less than 2 weeks. The exceptions are strong rainstorms (more than $\sim 12 \mathrm{~mm} /$ day) where the drip ER-G1 reacts within $12 \mathrm{hr}$. In contrast to ER-G1, the drip rate of ER-76 responds to precipitation events only after 1 to 2 months (Borsato 1997).

\section{Sample Preparation}

Drip water samples were collected monthly from November 2005 to October 2007. Samples at site ER-G1 were collected during each cave visit (within 2 hr), except for July and November 2006 and September 2007 when the drip rates were too low. In these months, aggregate drip water collected during the previous month was sampled. No sample is available for February 2006 because the risk of avalanches did not permit us to reach the cave. The March 2006 sample was lost during sample preparation. Drip water from site ER-76 was sampled as 1-month aggregate samples due to the consistently low discharge with the exception of the March 2006 sample, which represents 2 months. Sample preparation for accelerator mass spectrometry (AMS) ${ }^{14} \mathrm{C}$ measurement was performed at the ${ }^{14} \mathrm{C}$ laboratory of the Heidelberg Academy of Sciences. About $100 \mathrm{~mL}$ of drip water was acidified with $\mathrm{HCl}$ in vacuo. The evolved $\mathrm{CO}_{2}$-water vapor mixture was separated first by freezing the water vapor in a dry-ice cold trap. The remaining $\mathrm{CO}_{2}$ was captured in a glass vessel cooled with liquid nitrogen. The $\mathrm{CO}_{2}$ was then converted to $\mathrm{C}$ in a combustion line at $575^{\circ} \mathrm{C}$ via the reaction $\mathrm{CO}_{2}$ $+2 \mathrm{H}_{2} \rightarrow \mathrm{C}+\mathrm{H}_{2} \mathrm{O}$ using an iron catalyst. After the $\mathrm{C}$ precipitated on the iron, the $\mathrm{C}$-iron mixture was pressed into AMS targets and sent to the ${ }^{14} \mathrm{C}$ laboratories at Lund University (samples collected November 2005 to August 2007) and Zurich (September-October 2007), respectively (Table 1).

Table $1{ }^{14} \mathrm{C}$ activity and $\delta^{13} \mathrm{C}$ results of drip water samples (sites ER-G1, ER-76). Typical error of DIC $\delta^{13} \mathrm{C}$ measured at Innsbruck University is $0.1 \%(1 \sigma)$. Differences in $\delta^{13} \mathrm{C}$ between AMS and Innsbruck data are due to additional fractionation effects in the ion source of the AMS.

\begin{tabular}{|c|c|c|c|c|c|c|c|}
\hline $\begin{array}{l}\text { Sample } \\
\text { name }\end{array}$ & $\begin{array}{l}\text { Sampling } \\
\text { date }\end{array}$ & $\begin{array}{l}\text { Lab nr } \\
\text { Heidelberg } \\
\text { (HD) }\end{array}$ & $\begin{array}{l}\text { Lab nr } \\
\text { Lund (LuS)/ } \\
\text { Zurich (EM) }\end{array}$ & $\begin{array}{l}{ }^{14} \mathrm{C} \text { activity } \\
(\mathrm{pMC})\end{array}$ & $\begin{array}{l}1-\sigma \\
\text { error } \\
(\mathrm{pMC})\end{array}$ & $\begin{array}{l}\delta^{13} \mathrm{C} \\
(\mathrm{AMS}) \\
(\%)\end{array}$ & $\begin{array}{l}\delta^{13} \mathrm{C} \\
\text { (Innsbruck) } \\
(\%)\end{array}$ \\
\hline ER-G1 47 & Nov 2005 & HD-24871 & LuS50011 & 98.04 & 0.32 & -7.9 & -11.2 \\
\hline ER-G1 48 & Dec 2005 & HD-24882 & LuS50012 & 102.07 & 0.36 & -7.9 & -12 \\
\hline ER-G1 49 & Jan 2006 & HD-24884 & LuS50013 & 102.66 & 0.39 & -14.1 & -11.8 \\
\hline ER-G1 50 & Feb 2006 & & & & & & \\
\hline ER-G1 51 & Mar 2006 & & & & & & -11.6 \\
\hline ER-G1 52 & Apr 2006 & HD-25302 & LuS50082 & 97.13 & 0.34 & -9.9 & -11.7 \\
\hline ER-G1 53 & May 2006 & HD-25304 & LuS50084 & 99.44 & 0.38 & -6.8 & -11.9 \\
\hline ER-G1 54 & Jun 2006 & HD-25306 & LuS50086 & 101.33 & 0.36 & -0.7 & -12.3 \\
\hline ER-G1 55 & Jul 2006 & HD- 25348 & LuS50088 & 103.6 & 0.39 & -13.5 & -12 \\
\hline ER-G1 56 & Aug 2006 & HD- 25410 & LuS50090 & 103.4 & 0.38 & -13.7 & -11.5 \\
\hline ER-G1 57 & Sep 2006 & HD-25464 & LuS50144 & 102.68 & 0.45 & -5.9 & -12.1 \\
\hline ER-G1 58 & Oct 2006 & HD-25596 & LuS50207 & 101.26 & 0.4 & -6.2 & -12.2 \\
\hline ER-G1 59 & Nov 2006 & HD-25738 & LuS50205 & 101.22 & 0.38 & -16.2 & -10.3 \\
\hline ER-G1 60 & Dec 2006 & HD-25789 & LuS50208 & 101.45 & 0.39 & -18.7 & -12.3 \\
\hline ER-G1 61 & Jan 2007 & HD-25791 & $\mathrm{JuS} 50203$ & 104.01 & 042 & -16.1 & -12.3 \\
\hline ER-G1 62 & Feb 2007 & HD-25822 & LuS50201 & 99.24 & 0.49 & 3.8 & -11.8 \\
\hline ER-G1 63 & Mar 2007 & HD-25974 & LuS50256 & 100.06 & 0.4 & -13.2 & -12.1 \\
\hline ER-G1 64 & Apr 2007 & HD-25979 & LuS50258 & 100.92 & 0.43 & -13.1 & -11.8 \\
\hline ER-G1 65 & May 2007 & HD-26047 & LuS50260 & 101.12 & 0.55 & -5.3 & -12.8 \\
\hline ER-G1 66 & Jun 2007 & HD-26202 & LuS50357 & 101.64 & 0.49 & -12.3 & -11.9 \\
\hline ER-G1 67 & Jul 2007 & HD-26266 & LuS50361 & 103.89 & 0.39 & -16.9 & -12.3 \\
\hline ER-G1 68 & Aug 2007 & HD-26384 & LuS50364 & 104 & 0.39 & -13 & -12.3 \\
\hline ER-G1 69 & Sep 2007 & HD-26475 & EM1005 & 102.61 & 0.26 & -11.6 & -12 \\
\hline
\end{tabular}


Table $1{ }^{14} \mathrm{C}$ activity and $\delta^{13} \mathrm{C}$ results of drip water samples (sites ER-G1, ER-76). Typical error of DIC $\delta^{13} \mathrm{C}$ measured at Innsbruck University is $0.1 \%(1 \sigma)$. Differences in $\delta^{13} \mathrm{C}$ between AMS and Innsbruck data are due to additional fractionation effects in the ion source of the AMS. (Continued)

\begin{tabular}{|c|c|c|c|c|c|c|c|}
\hline $\begin{array}{l}\text { Sample } \\
\text { name }\end{array}$ & $\begin{array}{l}\text { Sampling } \\
\text { date }\end{array}$ & $\begin{array}{l}\text { Lab nr } \\
\text { Heidelberg } \\
\text { (HD) }\end{array}$ & $\begin{array}{l}\text { Lab nr } \\
\text { Lund (LuS)/ } \\
\text { Zurich (EM) }\end{array}$ & $\begin{array}{l}{ }^{14} \mathrm{C} \text { activity } \\
\text { (pMC) }\end{array}$ & $\begin{array}{l}1-\sigma \\
\text { error } \\
(\mathrm{pMC}) \\
\end{array}$ & $\begin{array}{l}\delta^{13} \mathrm{C} \\
(\mathrm{AMS}) \\
(\%) \\
\end{array}$ & $\begin{array}{l}\delta^{13} \mathrm{C} \\
\text { (Innsbruck) } \\
(\%)\end{array}$ \\
\hline ER-G1 70 & Oct 2007 & HD-26477 & EM1007 & 101.49 & 0.25 & -11.2 & -12.1 \\
\hline ER-76 47 & Nov 2005 & HD-24870 & LuS50014 & 100.1 & 0.38 & -12 & -11.1 \\
\hline ER-76 48 & Dec 2005 & HD-24881 & LuS50015 & 101.62 & 0.36 & -4.7 & -11 \\
\hline ER-76 49 & Jan 2006 & HD-24883 & LuS50016 & 101.62 & 0.34 & -1.3 & -11.1 \\
\hline ER-76 50 & Feb 2006 & & & & & & \\
\hline ER-76 51 & Mar 2006 & HD-25032 & LuS50017 & 102.27 & 0.42 & -6.9 & -10.8 \\
\hline ER-76 52 & Apr 2006 & HD-25301 & LuS50091 & 99.13 & 0.41 & -6.1 & -10.4 \\
\hline ER-76 53 & May 2006 & HD-25303 & LuS50083 & 99.77 & 0.35 & -9.6 & -11.6 \\
\hline ER-76 54 & Jun 2006 & HD-25305 & LuS50085 & 100.25 & 0.35 & -11 & -12 \\
\hline ER-76 55 & Jul 2006 & HD-25349 & LuS50087 & 101.81 & 0.36 & -16.4 & -11.5 \\
\hline ER-76 56 & Aug 2006 & HD-25409 & LuS50089 & 98.64 & 0.36 & -12.5 & -11.6 \\
\hline ER-76 57 & Sep 2006 & HD-25463 & LuS50145 & 101.53 & 0.42 & -15.4 & -11.1 \\
\hline ER-76 58 & Oct 2006 & HD-25596 & LuS50207 & 100.14 & 0.39 & -16.9 & -11.6 \\
\hline ER-76 59 & Nov 2006 & HD-25738 & LuS50205 & 99.82 & 0.39 & -18.2 & -11.1 \\
\hline ER-76 60 & Dec 2006 & HD-25788 & LuS50209 & 98.98 & 0.38 & -15.9 & -11.4 \\
\hline ER-76 61 & Jan 2007 & HD-25790 & LuS50202 & 101.53 & 0.39 & -11.6 & -11.3 \\
\hline ER-76 62 & Feb 2007 & HD-25821 & LuS50200 & 101.94 & 0.41 & -7.7 & -10.7 \\
\hline ER-76 63 & Mar 2007 & HD-25973 & LuS50255 & 93.17 & 0.37 & -15.1 & -12.2 \\
\hline ER-76 64 & Apr 2007 & HD-25978 & LuS50257 & 102.08 & 0.4 & -12.4 & -11.2 \\
\hline ER-76 65 & May 2007 & HD-26046 & LuS50259 & 101.81 & 0.46 & -8.8 & -12.1 \\
\hline ER-76 66 & Jun 2007 & HD-26201 & LuS50356 & 98.68 & 0.36 & -14 & -11.1 \\
\hline ER-76 67 & Jul 2007 & HD-26265 & LuS50360 & 100.79 & 0.54 & -13.9 & -12.1 \\
\hline ER-76 68 & Aug 2007 & HD-26384 & LuS50364 & 101.35 & 0.37 & -11.2 & -12 \\
\hline ER-76 69 & Sep 2007 & HD-26474 & EM1004 & 99.71 & 0.25 & -11.6 & -11.5 \\
\hline ER-76 70 & Oct 2007 & HD-26476 & EM1006 & 100.93 & 0.24 & -10.2 & -11.6 \\
\hline
\end{tabular}

The soil water samples were collected with a lysimeter situated above the center of the cave, nearly exactly above drip location ER-G1, and not shaded by the vegetation canopy. The lysimeter is comprised of a plastic tube with a large ceramic cup at the bottom. The water was collected with a vacuum pump. The soil water samples were collected at $1 \mathrm{~m}$ depth. To minimize $C$ isotope fractionation effects, we followed the sampling procedure described in Spötl (2005) when collecting soil and drip water. The method for air sample collection and transport as suggested by Spötl (2004) was performed to minimize alterations of the stable $\mathrm{C}$ isotopic composition. DIC $\delta^{13} \mathrm{C}$ and $\delta^{18} \mathrm{O}$ values of monthly drip and soil water samples as well as $\delta^{13} \mathrm{C}$ of air samples were analyzed at Innsbruck University ( $\pm 0.1 \%$ precision) using a Delta ${ }^{\text {plus }} \mathrm{XL}$ isotope ratio mass spectrometer (see Spötl 2005). $\delta^{13} \mathrm{C}$ and $\delta^{18} \mathrm{O}$ values are reported on the VPDB scale. All air isotope samples were analyzed within $72 \mathrm{hr}$ after sampling.

The concentration of dissolved $\mathrm{Ca}^{2+}$ in the drip water was analyzed at Heidelberg University using an ICP-OES VISTA MXP (VARIAN) with an internal $1 \sigma$ of $<1 \%$. NIST 1643 e was used as a standard, which has long-term reproducibility of $1 \mathrm{mg} / \mathrm{L}(3 \%)$. $\mathrm{pH}$ measurements were carried out in the field and directly within the cave to avoid temperature effects, by using a multiparameter 340I meter (WTW) equipped with a highly sensitive probe ( $\pm 0.05 \mathrm{pH}$ units) and temperature probe. Cave air $\mathrm{pCO}_{2}$ was measured with a Vaisala Meter GM70 with GMP222 probe (accuracy at $25^{\circ} \mathrm{C}: \pm 20 \mathrm{ppm}$ ). 


\section{RESULTS AND INTERPRETATION}

$\delta^{13} \mathrm{C}$ and $\delta^{18} \mathrm{O}$

Soil air and soil water $\delta^{13} \mathrm{C}$ values of DIC as well as the $\mathrm{O}$ isotopic composition of soil and cave water were investigated in order to evaluate the drip water $\mathrm{C}$ isotope data in terms of processes influencing the annual variability. The $\delta^{18} \mathrm{O}$ values of soil water at $1 \mathrm{~m}$ depth (Figure 1a) indicate a strong annual $\delta^{18} \mathrm{O}$ cycle $(\sim 3 \%)$ despite the lack of data in some months where it was not possible to collect soil water. In contrast, drip water $\delta^{18} \mathrm{O}$ values show little interannual variation $(\sim 0.5 \%)$, indicating a well-mixed karst water reservoir feeding ER-G1 (Figure 1a). Furthermore, the elevated $\mathrm{Ca}^{2+}$ values in soil water (Figure 1a) indicate that at $1 \mathrm{~m}$ below the surface, significant calcite dissolution has already occurred as also shown in other studies (e.g. Larssen et al. 1998). The concentration of soil water $\mathrm{Ca}^{2+}$ shows a large variation of $\sim 35 \mathrm{mg} / \mathrm{L}$. This variation diminishes in the karst aquifer and results in nearly constant $\mathrm{Ca}^{2+}$ concentrations in the drip water of location ER-G1 (Figure 1a). The same pattern is observed in the stable $\mathrm{C}$ isotope composition of soil air, soil water (Figure 1b), and drip water of ER-G1 and ER-76 (Figure 2) (see also Frisia et al. 2010). The $\delta^{13} \mathrm{C}$ value of soil air and soil water has varied between November 2005 and October 2007 by 3\%o (Figure 1b). This variation is consistent with the annual cycle of soil air $\delta^{13} \mathrm{C}$ as observed in other studies (e.g. Andrews et al. 1999; Ekblad and Högberg 2001; Bowling et al. 2002; Gorczyca et al. 2003; Steinmann et al. 2004). Maximum values are reached in winter, when vegetation respiration and dead organic material decomposition are reduced with respect to the warm seasons when the most negative values are observed. The soil air $\delta^{13} \mathrm{C}$ shows the opposite behavior to the soil air $\mathrm{pCO}_{2}$. Both findings can be explained by the soil respiration rate, which is lower in winter than in summer, and with the diffusion of the respired soil air $\mathrm{CO}_{2}$ to the free atmosphere as demonstrated by Cerling (1984). The soil respiration rate, in turn, depends strongly on temperature and precipitation (Schlesinger 1977). Thus, the annual cycles of temperature and amount of precipitation explain the minimum and maximum of soil air $\delta^{13} \mathrm{C}$ in September and March, respectively. The soil water $\delta^{13} \mathrm{C}$ cycle is a consequence of water in isotopic equilibrium with the surrounding air. In months where no data are shown, the lysimeter was empty due to dry conditions of the atmosphere (less rain or a high amount of evapotranspiration) or frozen soil conditions. Isotope analysis on soil air started in April 2006.

The $\delta^{13} \mathrm{C}$ data of the drip water DIC of ER-G1 and ER-76 (Figure 2) reveal only a subtle interannual variability, with only small deviations from the mean values of both drip sites. The $3 \%$ range seen in the soil water is completely attenuated and no clear annual cycle is visible. Hence, the variation in the DIC in drip water $\delta^{13} \mathrm{C}$ can hardly be inferred from the soil water $\delta^{13} \mathrm{C}$ cycle. The slow drip site ER-76 shows on average $0.5 \%$ more negative $\delta^{13} \mathrm{C}$ values than the fast drip site ER-G1. The 2yr means are $-11.9 \%$ (ER-G1) and $-11.4 \%$ (ER-76).

\section{Radiocarbon Measurements}

In contrast to $\delta^{13} \mathrm{C},{ }^{14} \mathrm{C}$ measurements on DIC in drip water reveal a distinct annual pattern over the 2-yr sampling period (Figure 3). This pattern is more significant for the ${ }^{14} \mathrm{C}$ values of waters from the fast seasonal drip ER-G1 waters than for the slow seasonal drip ER-76. In the second year of ${ }^{14} \mathrm{C}$ activity measurements of ER-76, the pattern breaks down. The annual drip water characteristic consists of a trend towards increasing ${ }^{14} \mathrm{C}$ activity between November and January, followed by a strong decrease in the ${ }^{14} \mathrm{C}$ activity in February and March. Between March and July, a steady increase in ${ }^{14} \mathrm{C}$ activity occurs until the ${ }^{14} \mathrm{C}$ content decreases slightly until November. For most samples, the ${ }^{14} \mathrm{C}$ activity in DIC drip water samples of location ER-76 is lower than for drip ER-G1. The mean difference in the ${ }^{14} \mathrm{C}$ activity between both drip locations is $1.2 \mathrm{pMC}$. Furthermore, the variations of the ${ }^{14} \mathrm{C}$ content in DIC of the drip water from location ER-G1 are larger than those from ER-76. 


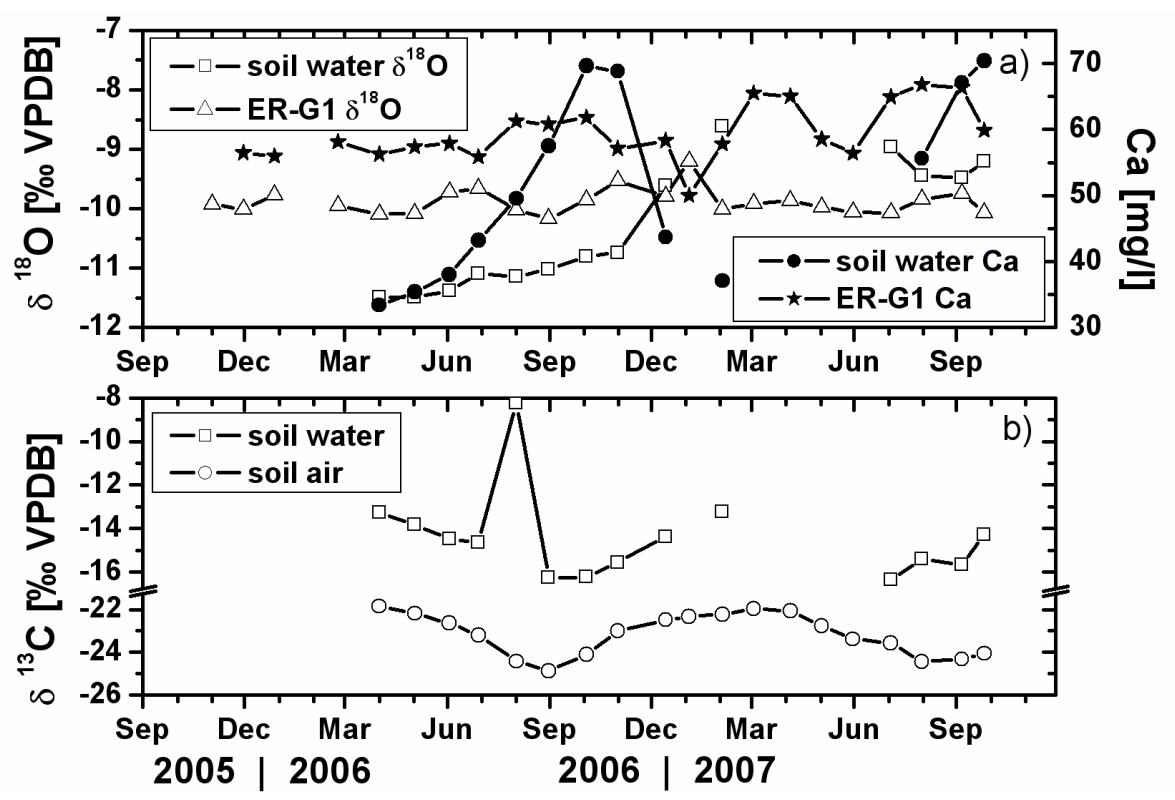

Figure 1 Monthly measured $\delta^{18} \mathrm{O}$ values (a) of soil water (open squares) and water of drip location ER-G1 (open triangles). The large difference of the soil water collected in summer and winter is smoothed in the karst system and results in almost constant $\delta^{18} \mathrm{O}$ values of the drip water. While soil water Ca concentrations (black circles) reveal large interannual variations, the Ca concentration of location ER-G1 (black stars) is more constant. (b) Shows the stable $\mathrm{C}$ isotopic composition of soil air (open circles) and soil water (open squares). The cyclicity of the $\delta^{13} \mathrm{C}$ signal in soil air is maintained in the soil water samples.

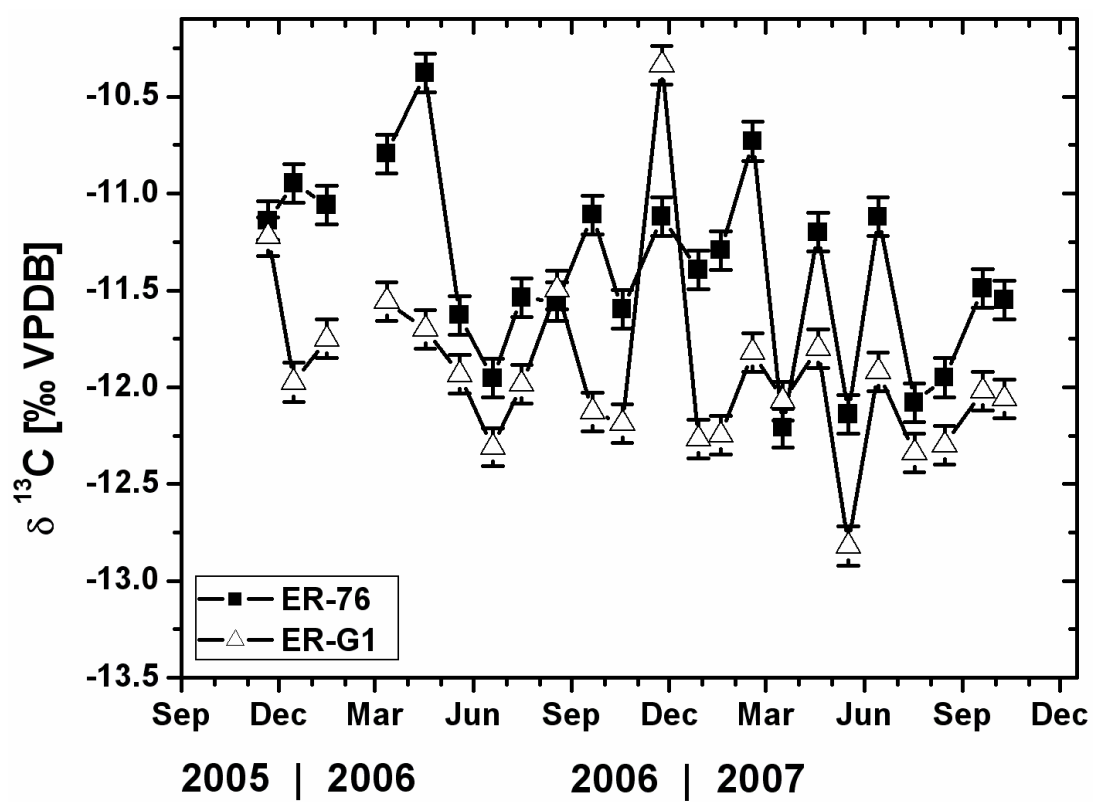

Figure 2 Monthly measured $\delta^{13} \mathrm{C}$ data of DIC in the drip water samples collected at sites ER-G1 (open triangles) and ER-76 (black squares) are fairly constant compared to the pronounced annual cycle of soil water DIC $\delta^{13} \mathrm{C}$ (Figure 1b). 


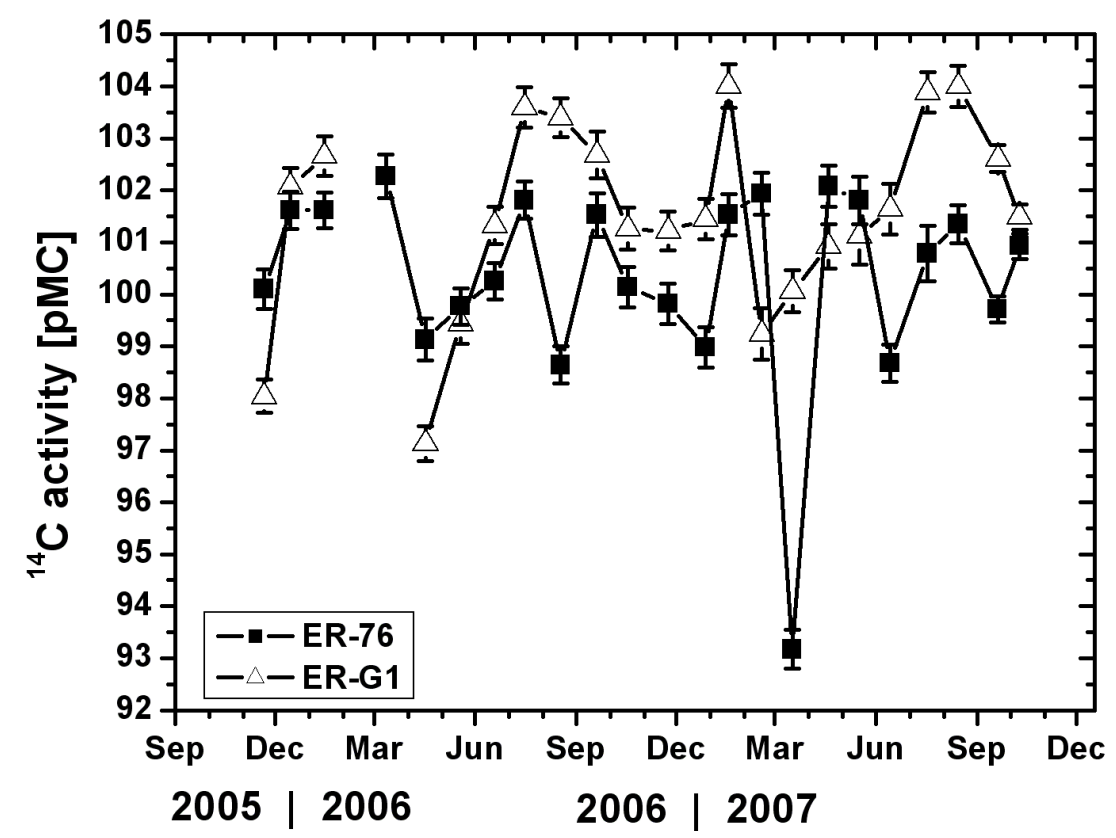

Figure 3 Monthly measured ${ }^{14} \mathrm{C}$ data of the drip water samples collected at drip locations ER-G1 (open triangles) and ER-76 (black squares) reveal a distinct annual cycle. Only the last year for ER76 did not fit the cycle.

Fohlmeister et al. (forthcoming) derived soil parameters for the soil above Ernesto Cave, which enable computation of the ${ }^{14} \mathrm{C}$ activity of the soil air. According to these parameters, the gaseous $\mathrm{CO}_{2}$ of the soil has a ${ }^{14} \mathrm{C}$ activity of $\sim 110 \mathrm{pMC}$ in the year 2006 . The mean ${ }^{14} \mathrm{C}$ value of drip site ERG1 is $\sim 101.5 \mathrm{pMC}$. Neglecting the small fractionation effects for ${ }^{14} \mathrm{C}$, the proportion of dead carbon originating from the host rock carbonate is approximately $8 \%$.

\section{pH Measurements and Drip Rates}

A distinct annual signal has been observed in the drip water $\mathrm{pH}$ (Figure 4). This had been interpreted as being modulated by degassing, because it follows the seasonal cave air $\mathrm{pCO}_{2}$ decrease (Figure 4), with higher $\mathrm{pH}$ in the cold season when cave $\mathrm{pCO}_{2}$ is at its lowest values (Frisia et al. 2000, 2010). However, the chemical composition of drip water from both sites is not in chemical equilibrium with cave air $\mathrm{CO}_{2}$. The cave air $\mathrm{pCO}_{2}$ is constant in the whole cave at any given time due to its ventilation characteristics, which are responsible for the large range of cave air $\mathrm{pCO}_{2}$ throughout the year. The main sources of cave air $\mathrm{pCO}_{2}$ are the outer atmosphere in winter and gaseous $\mathrm{CO}_{2}$ emerging from the karst in summer (Frisia et al. 2010). In both drip sites, decreasing $\mathrm{pH}$ values have been measured from late winter to autumn and increasing $\mathrm{pH}$ values from autumn to late winter. The $\mathrm{pH}$ of water from drip site ER-76 is more alkaline than the $\mathrm{pH}$ of drip water measured at the location ER-G1, but the $\mathrm{pH}$ variations in both drip sites are comparable.

Drip rate measurements at both locations reveal the seasonality of drips in the slow drip ER-76 and in the fast drip ER-G1 (Figure 5). The drip rate is controlled by the infiltration of meteoric water (Miorandi et al. 2010). However, calcite deposition below ER-76 occurs over a small radius and forms a stalagmite displaying a marked annual cyclicity (Frisia et al. 2003), whereas under ER-G1 deposition is spread over a large area and lacks evidence of annularity. Hence, seasonality of the drips does not necessarily translate into seasonality in the calcite precipitated from these drips. 


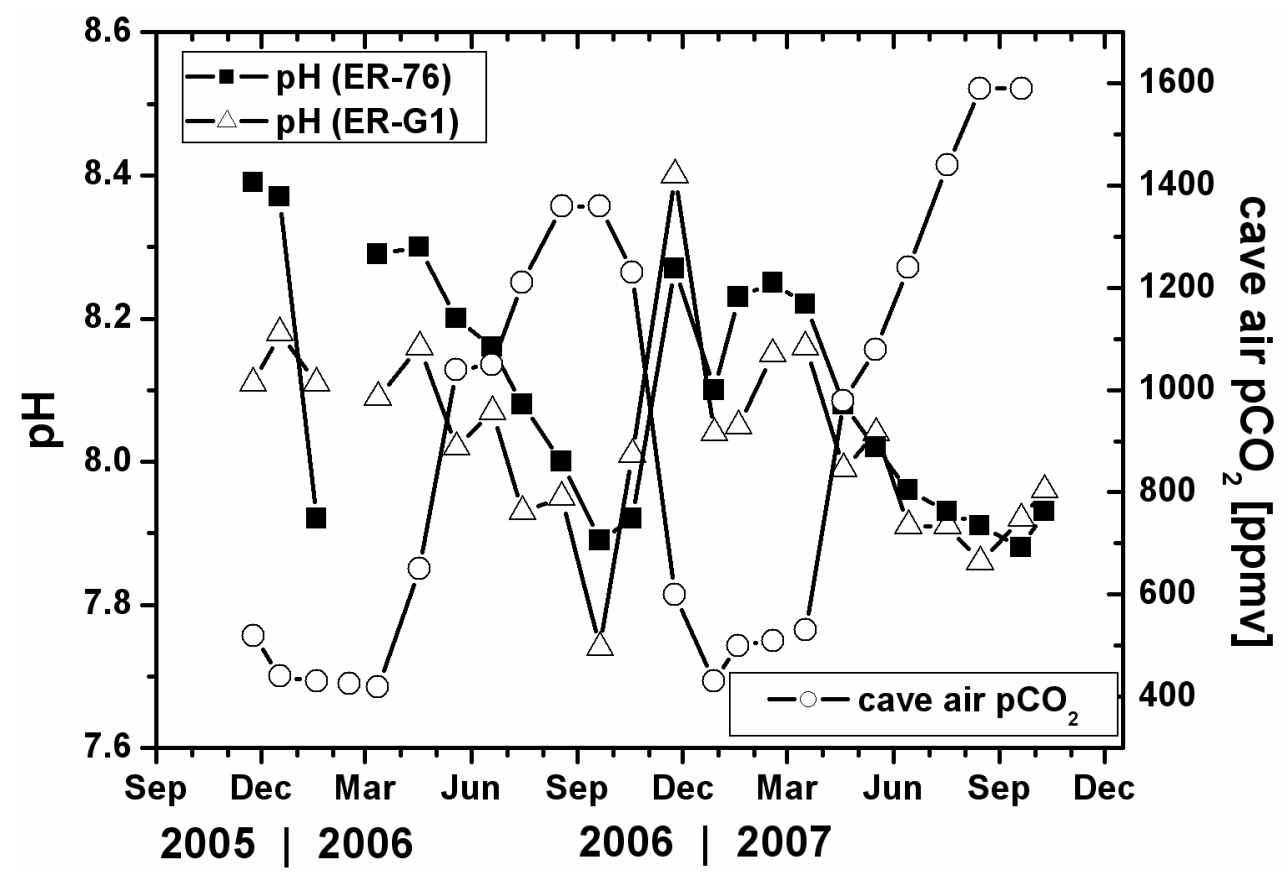

Figure 4 Monthly measured pH values of drip water from locations ER-G1 (open triangles) and ER-76 (black squares) reveal a synchronous behavior. Water from ER-76 is in general more alkaline than ER-G1. Cave air pCO (open circles) shows an inverse pattern as $\mathrm{pH}$ resulting in a high anticorrelation between both variables $(r=-0.87$, $p<0.0001)$.

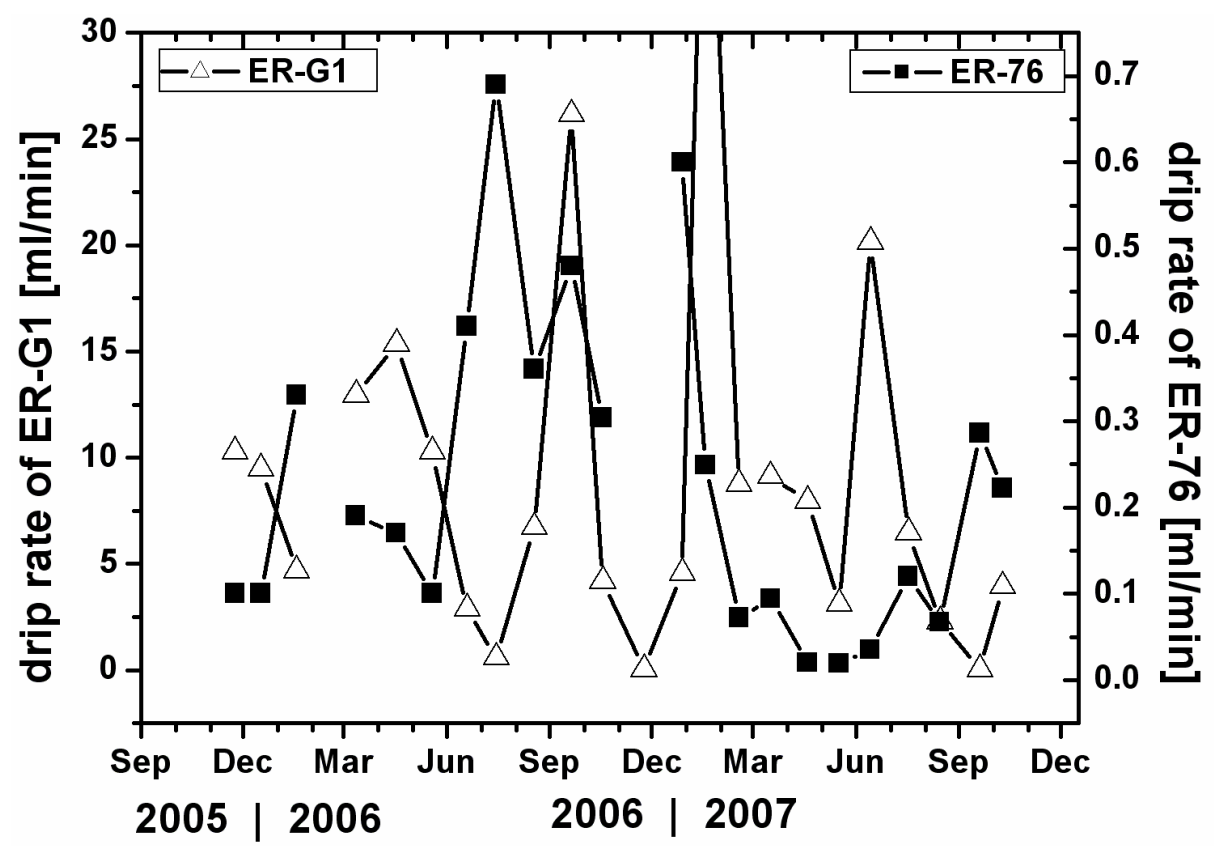

Figure 5 Drip site ER-76 (black squares) has lower drip rates than ER-G1 (open triangles). Nevertheless, both sites show large variations in drip rate, although they are not simultaneous. 


\section{DISCUSSION}

\section{Implications for Soil Processes}

The smoothing of the $\delta^{18} \mathrm{O}$ signal in drip water from location ER-G1 compared to the soil water (Figure 1a) is interpreted as mixing in the karst aquifer reservoir occurring below the sampling depth of the soil water (1 m) as stated in Fairchild et al. (2000) and Frisia et al. (2005). Due to the shortterm monitoring of the oxygen isotopes in the water, it is impossible to provide any indication about the resolution of the time signal encoded in the mixed oxygen isotope values. The oxygen isotope values of drip waters at both drip sites indicate a mixed average over a minimum of $2 \mathrm{yr}$. It is reasonable, therefore, to infer that the $\delta^{13} \mathrm{C}$ values of drip water at both monitored drips (Figure 2) also reflect some mixing in the soil and epikarst. The $3 \%$ variation in $\delta^{13} \mathrm{C}$ observed in soil air and water in the $2 \mathrm{yr}$ of observation is, in fact, smoothed in the aquifer reservoir and leads to a relatively constant $\delta^{13} \mathrm{C}$ signal in the drip waters. The mixing hypothesis is also supported by the seasonal pattern of soil air and soil water $\delta^{13} \mathrm{C}$ values (Figure $2 \mathrm{~b}$ ), because the seasonality is not reproduced by the $\delta^{13} \mathrm{C}$ variability of the drip water. Therefore, other processes occur in the karst, which account for the small variation of $\delta^{13} \mathrm{C}$ of DIC in drip water. These effects can be explained by interpreting the ${ }^{14} \mathrm{C}$ measurements on drip water (Figure 3). First, we will focus on drip location ER-G1, which responds quickly to precipitation events, rather than on the slow drip location ER-76.

For further consideration, we assume a groundwater reservoir above Ernesto Cave that is not completely saturated with respect to calcite. Furthermore, we assume that the groundwater has ${ }^{14} \mathrm{C}$ values generated by a calcite dissolution process under predominantly open dissolution conditions. The first condition is satisfied by the fact that when an unsaturated solution joins a reservoir the resulting solution is also unsaturated. Additionally, our assumption of the unsaturated aquifer reservoir is supported by the theoretical finding that mixing of 2 saturated solutions each in equilibrium with different $\mathrm{pCO}_{2}$ leads to an unsaturated solution (Dreybrodt 1988). The mixed solution is expected to emerge mainly under open dissolution conditions because the carbonate dissolution occurs in the upper soil layers and the solution remains in contact with the infinite soil $\mathrm{CO}_{2}$ reservoir. This assumption is underpinned by the $\delta^{13} \mathrm{C}$ values of soil air and water (Figure 1b) in combination with the soil water $\mathrm{Ca}^{2+}$ data (Figure 1a). The mean $\mathrm{Ca}^{2+}$ concentration of the soil water is $\sim 50 \mathrm{mg} / \mathrm{L}$ and, hence, large parts of the dissolution process takes place within the first meter of the soil (compare with the mean drip water $\mathrm{Ca}^{2+}$ content of ER-G1 [Figure 1a], which is $\sim 60 \mathrm{mg} / \mathrm{L}$ ). Figure $1 \mathrm{~b}$ shows a mean $\delta^{13} \mathrm{C}$ enrichment between soil air $\mathrm{CO}_{2}$ and DIC of soil water of $\sim 8.5 \%$. At a mean soil water temperature of $\sim 7^{\circ} \mathrm{C}$ and a mean soil water $\mathrm{pH}$ value of 7.4 , the aqueous $\mathrm{CO}_{2}$ in the solution is $\sim 10 \%$ and the bicarbonate is $\sim 90 \%$ of the total $\mathrm{C}$ in the solution. According to the fractionation constants reported in Mook and de Vries (2000) the mean $\delta^{13} \mathrm{C}$ enrichment between soil air $\mathrm{CO}_{2}$ and DIC of soil water should be $\sim 8.85 \%$. Theoretical and measured fractionation factors are in the same range and point to calcite dissolution, which is in equilibrium with its surrounding soil air $\mathrm{CO}_{2}$. The stable $\mathrm{C}$ isotope value of the host-rock carbonate of around 0 to $+1 \%$ (published by Avanzini et al. [1997], who measured $\delta^{13} \mathrm{C}$ on the same rock formation that also covers Grotta di Ernesto) is not seen in the soil water. Hence, open conditions of carbonate dissolution are very likely to prevail in the first meter of the soil cover.

\section{Implications for Karst Aquifer Behavior on Drip Location ER-G1}

Carbon from SOM and from carbonates are the most important $\mathrm{C}$ sources from which the $\mathrm{C}$ species in the drip water are derived. Therefore, these pools are responsible for a seasonal signal like the one shown in Figure 3. Theoretically, the annual ${ }^{14} \mathrm{C}$ activity pattern as seen in drip water can be explained by changes in the composition of the total soil $\mathrm{CO}_{2}$ alone, which is derived from SOM res- 
ervoirs of different ages (Dörr and Münnich 1986; Tegen and Dörr 1996; Genty et al. 1998; Genty and Massault 1999; Trumbore 2000). The percentages of the different reservoirs to total soil $\mathrm{pCO}_{2}$ change the ${ }^{14} \mathrm{C}$ composition of soil air $\mathrm{CO}_{2}$ throughout the year. However, as argued above, any seasonal soil signal is attenuated by mixing processes in the soil above Grotta di Ernesto, and, thus the contribution from SOM of different ages is hardly responsible for the cycle observed in drip water ${ }^{14} \mathrm{C}$. Hence, this cannot be the process driving the annual cycle in ${ }^{14} \mathrm{C}$ activity in drip water of Grotta di Ernesto.

Another effect on the $\mathrm{C}$ of the drip water is the degassing of $\mathrm{CO}_{2}$ inside the cave, plus some possible equilibration of $\mathrm{C}$ isotopes in the solution with cave air. The degassing of the drip water observed at the same time that water was running down the stalactite (Frisia et al. 2000; Miorandi et al. 2010), did not affect the $\mathrm{Ca}^{2+}$ concentration because the solution must first exceed a certain SI value (Nielsen and Toft 1984) before $\mathrm{Ca}^{2+}$ can precipitate. During degassing, the composition of the $\mathrm{C}$ isotope changes, whereas the changes for ${ }^{14} \mathrm{C}$ are roughly twice as high as for ${ }^{13} \mathrm{C}$ (Saliège and Fontes 1984; Mook and de Vries 2000). Comparing the mean $\delta^{13} \mathrm{C}$ of soil water (about $-14.4 \%$ ) and drip water (about $-11.9 \%$ ) (Figure 1b) indicates that at maximum a change of $6 \%$ o $(0.6 \mathrm{pMC})$ in ${ }^{14} \mathrm{C}$ activity can occur due to the degassing of $\mathrm{CO}_{2}$. This is an order of magnitude smaller than the variations of the ${ }^{14} \mathrm{C}$ data during the measurement period (Figure 3). Hence, the degassing process has little potential to vary the ${ }^{14} \mathrm{C}$ activity and $\mathrm{Ca}^{2+}$ concentration and, therefore, is not significant for the collected drip water. In addition, it is possible that $\mathrm{C}$ exchange between the DIC in the water and the cave air affects the carbon isotope composition of the DIC in drip water. However, at Grotta di Ernesto also cave air $\delta^{13} \mathrm{C}$ was measured during the investigated period. Summer values of cave air $\delta^{13} \mathrm{C}$ are about $-20 \%$ and winter values are around $-12 \%$ (Frisia et al. 2010). Hence, if the effect of $\mathrm{C}$ exchange is pronounced in the cave, then the $\delta^{13} \mathrm{C}$ of the slow drip ER-76 should be affected most, because the drip waters of ER-76 are collected continuously over a 1-month period and, hence, have time to equilibrate. However, we did not observe variations in the $\delta^{13} \mathrm{C}$ of the drip water, which are similar to the change of the cave air $\delta^{13} \mathrm{C}$. We therefore conclude that the process of $\mathrm{C}$ exchange between DIC in drip water and cave air $\mathrm{CO}_{2}$ is not important for the drip water that we collected.

The third possibility is that the observed variability in the ${ }^{14} \mathrm{C}$ signal of DIC in drip water originates from the carbonate dissolution processes in the soil zone and the epikarst, either by the way the carbonate dissolves or by $\mathrm{C}$ exchange processes between water and carbonate rock. At first, we deal with changes in the degree of open and closed carbonate dissolution conditions. As already discussed, the water in the well-mixed groundwater reservoir is undersaturated and emerges under open dissolution conditions. When the carbonate of the karst aquifer dissolves until the saturation is achieved, the condition of carbonate dissolution can vary. Under completely open dissolution conditions, much more carbonate can dissolve as compared to completely closed conditions (e.g. Hendy 1971; Salomons and Mook 1984). Variations in the $\mathrm{Ca}^{2+}$ concentration indicate that there are changes in the condition of calcite dissolution. These changes also control the ${ }^{14} \mathrm{C}$ activity of the drip water. If we assume, a priori and without loss of generality, that in the month with the highest measured $\mathrm{Ca}^{2+}$ concentration $(66.8 \mathrm{mg} / \mathrm{L}$, August 2007) the carbonate was dissolved under the most open conditions of all observed months, and if we assume further that the deviations from that $\mathrm{Ca}^{2+}$ value are due to changes in the degree of open and closed carbonate dissolution, then the $\mathrm{Ca}^{2+}$ concentration should correlate with the measured ${ }^{14} \mathrm{C}$ data. However, a correlation is not observed. This theoretical correlation cannot be disturbed by the degassing process in the cave because there is no potential to disturb a correlation between ${ }^{14} \mathrm{C}$ and $\mathrm{Ca}^{2+}$ concentration as shown above. Hence, there has to be another process overlying the varying condition of carbonate dissolution. 
This process has to occur also in the karst aquifer and seems to be the $\mathrm{C}$ isotope exchange between DIC and the host-rock carbonate. To demonstrate the impact of the $\mathrm{C}$ isotope exchange on the ${ }^{14} \mathrm{C}$ activity, we use the drip rate of location ER-G1, which is a value for the residence time of the water in the karst aquifer. Figure 6 shows that there is a strong correlation between ${ }^{14} \mathrm{C}$ activity and drip rate. From very low drip rates up to drip rates of $\sim 15 \mathrm{~mL} / \mathrm{min}$, there is a strong negative linear correlation between these 2 parameters $(r=-0.7, p=0.001)$. Above drip rates of $\sim 15 \mathrm{~mL} / \mathrm{min}$, a threshold is crossed and the correlation breaks down. Above the threshold, the ${ }^{14} \mathrm{C}$ activity increases with increasing drip rate. Therefore, the correlation calculation was performed without the samples lying above the threshold, which are marked as squares within parentheses.

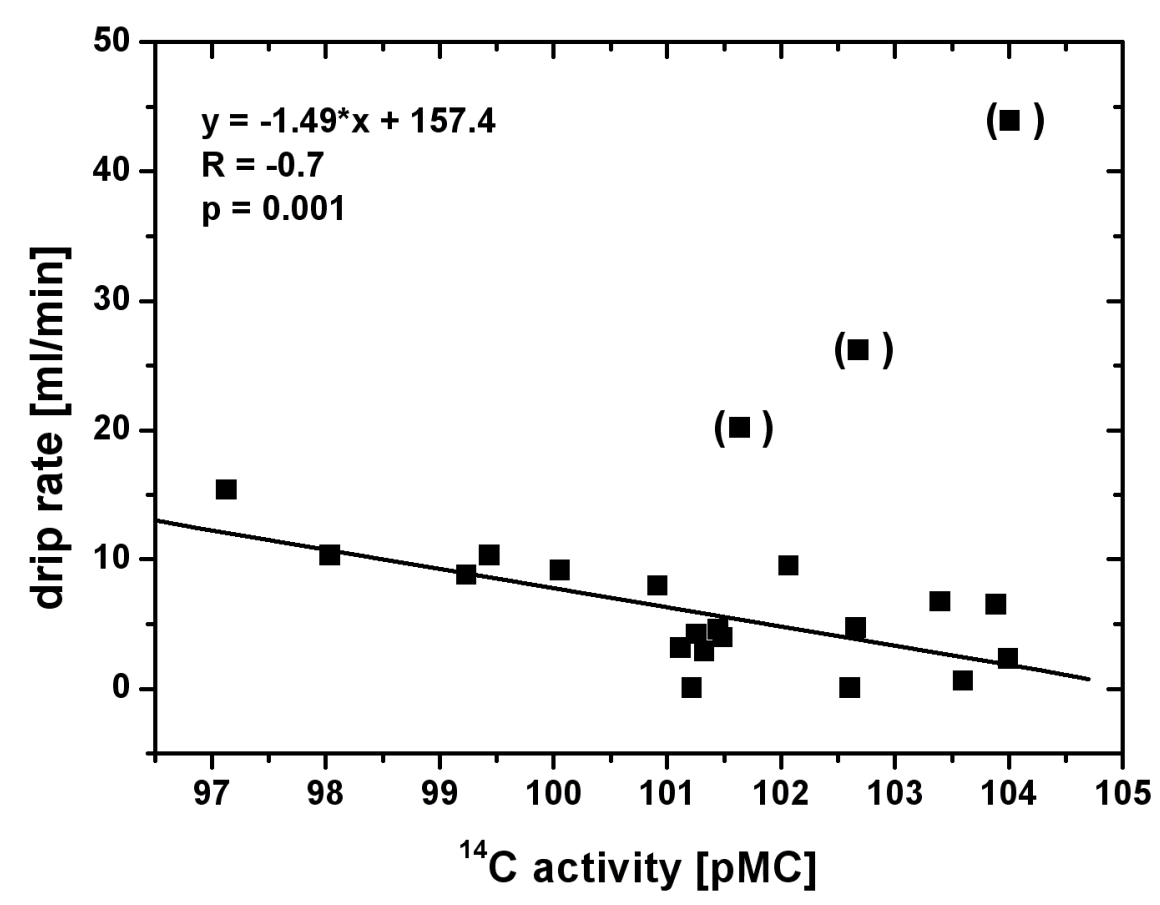

Figure 6 Correlation of monthly drip rate at ER-G1 and ${ }^{14} \mathrm{C}$ activity of DIC in drip water, indicating a strong relationship. Calculations were performed without the values in parentheses (see text).

For ER-G1, the linear correlation below the threshold can be explained by the karst residence time of the water. Water, which has a longer residence time in the karst, is allowed to exchange more $\mathrm{C}$ between the water and the carbonate rock. Accordingly, the drip water sampled during high drip rates has a longer residence time in the water reservoir than the water, which arrives in the cave during low drip rates. At first glance, this seems to be contradictory. However, water emerging in the cave at high drip rates came into the karst aquifer during times that experience mostly low infiltration conditions and stayed there a relatively long time until a strong infiltration event pushed this water very quickly into the cave. When the infiltration event stopped, large parts of the water from the infiltration event are shortly above the cave and this water, which has a relatively short residence time in the karst, has high ${ }^{14} \mathrm{C}$ values, and emerged in the cave during times with low drip rates.

The existence of the threshold implies that at least 2 different water flows feed drip location ER-G1. If the drip rates are below the threshold, the water is supplied by a steady flow, most likely a matrix one (Fairchild et al. 2006). Such flow allows for more $\mathrm{C}$ isotope exchange. The ${ }^{14} \mathrm{C}$ activity depends 
on this drip rate range only in the time when the water is percolating through the karst aquifer. If an enormous infiltration event occurs, a threshold is crossed and water from another flow path is added to drip location ER-G1. This process is similar to those modeled for other caves in Fairchild et al. (2006). This additional water originates from fissure flow with water having less contact with the carbonate matrix; hence, less $\mathrm{C}$ can be exchanged. This water has to have higher ${ }^{14} \mathrm{C}$ activities than the water of the porous flow. Therefore, the variations in the ${ }^{14} \mathrm{C}$ activity of the drip water depend on the contribution of the different sources to the total drip water. If the threshold is crossed, then the ${ }^{14} \mathrm{C}$ activity of the drip water is higher with a larger contribution of water from fissure flow, resulting in very high drip rates.

With a host rock consisting of ancient marine carbonates, an opposite behavior to that described for ${ }^{14} \mathrm{C}$ activity should be established with respect to drip water $\delta^{13} \mathrm{C}$ (Criss et al. 2007). This is not observed due to $\mathrm{CO}_{2}$ degassing in the cave. The degassing process disturbs the signal of the stable $\mathrm{C}$ isotope (expressed in $\delta$ notation) more significantly than the radiogenic $\mathrm{C}$ isotope in drip water (expressed in pMC). Additionally, the amount of degassing varies within the analyzed period. Using the MIX4 program (Plummer et al. 1975; Fairchild et al. 1994), we virtually added $\mathrm{CO}_{2}$ to the drip water. The injected $\mathrm{CO}_{2}$ amount, which was needed to achieve the saturation state of the water with respect to calcite, covers a range from 0.09 up to $0.29 \mathrm{mmole} / \mathrm{L}$. The loss of $\mathrm{CO}_{2}$ in the range of the calculated amount yield an enrichment in $\delta^{13} \mathrm{C}$ of the water of about $0.2-0.6 \%$ if we assume isotopic equilibrium fractionation. The enrichment is larger if the fractionation does not occur in equilibrium.

\section{Implications for Karst Aquifer Behavior on Drip Location ER-76}

It is remarkable that the ${ }^{14} \mathrm{C}$ values of the slow seasonal drip ER-76 are generally lower than for the fast seasonal drip ER-G1 and that the signal is more attenuated (Figure 3). On the other hand, the $\delta^{13} \mathrm{C}$ values (Figure 2) are higher in general. Assuming that the drip water of both drip locations is fed by the same aquifer with the same isotopic composition, the difference between the $\mathrm{C}$ isotopes of both drip locations is related to karst hydrology or processes within the cave. Degassing of the solution during the 1-month sampling duration is a possible explanation for the enhanced $\delta^{13} \mathrm{C}$ values. The degassing process is being increasingly recognized as a very important cave process in a variety of environments (Spötl et al. 2005; Baldini et al. 2008), and has been documented at Grotta di Ernesto (Frisia et al. 2000). However, if only degassing acted, the enriched $\delta^{13} \mathrm{C}$ values should be accompanied by higher ${ }^{14} \mathrm{C}$ values in the $\mathrm{C}$ of the drip water (Figure 3). A higher $\delta^{13} \mathrm{C}$ value of $0.5 \%$ (the observed mean difference of the 2-yr period for both drip sites) would result in a higher mean ${ }^{14} \mathrm{C}$ activity of roughly $0.1 \mathrm{pMC}$ in drip ER-76 compared to ER-G1. However, a lower mean value of $1.2 \mathrm{pMC}$ in ER-76 was measured. Hence, degassing is not the only process responsible for higher $\delta^{13} \mathrm{C}$ values in drip water of ER-76 compared to ER-G1. Nevertheless, degassing will surely contribute to the total $\delta^{13} \mathrm{C}$ and ${ }^{14} \mathrm{C}$ signal of ER-76 drip water.

As mentioned previously, chemical reactions or isotopic $\mathrm{C}$ exchange between the solution and the soil and host rock carbonates explain lower ${ }^{14} \mathrm{C}$ activities and higher $\delta^{13} \mathrm{C}$ contents in drip water. That means either that the dissolution process in the pathway feeding ER-76 occurred under more closed conditions than in the pathway feeding ER-G1, or that C exchange processes between the $\mathrm{C}$ species in solution and the $\mathrm{C}$ of the host rock occurred to a larger extent in ER-76 compared to ERG1. Both drips, ER-76 and ER-G1, are classified as seasonal drips reacting to seasonal precipitation changes. Only the amount of discharge (roughly 2 orders of magnitude difference) and the soil residence time of water (around 2 months in ER-76 compared to 2 weeks for ER-G1; Borsato 1997) are different. This is a hint that for water of ER-76, C exchange between solution and carbonates is even more important than for ER-G1. 
The difference in $\mathrm{pH}$ between both drip waters is the more alkaline drip water of ER-76 compared to the ER-G1 drip water (Figure 4). Higher $\mathrm{pH}$ values can be attributed to degassing processes, to a more closed carbonate dissolution process, or to a combination of both. Unfortunately, no ion measurements were performed on drip water of ER-76 during that period, so that data is unavailable to differentiate between both processes. We speculate that most of the offset in the $\mathrm{pH}$ between ER-76 and ER-G1 is due to a more closed dissolution condition in the karst aquifer and that the seasonal pattern of the $\mathrm{pH}$ is due to the same strength of degassing effects occurring for ER-G1. The sum of all 3 processes - degassing, a more closed dissolution condition, and a more important $\mathrm{C}$ exchange process - have the potential to explain the $\mathrm{C}$ isotopes measurements.

We did not find a correlation between drip rate and ${ }^{14} \mathrm{C}$ activity for drip site ER-76. The attenuation of the ${ }^{14} \mathrm{C}$ signal in drip water of ER-76 compared to ER-G1 is very likely attributed to the longer soil and karst residence time of this water, which is consistent with the more muted seasonal drip behavior of ER-76. The longer residence time leads to higher mixing in the karst aquifer. Hence, the water derived under more open conditions in 1 month and under more closed conditions during the next month can account for the observed intermediate ${ }^{14} \mathrm{C}$ values.

\section{CONCLUSIONS}

We present data from a 2-yr monitoring involving $\mathrm{C}$ measurements on monthly drip water samples from 2 drip sites at Ernesto Cave. The ${ }^{14} \mathrm{C}$ measurements reveal a clear annual cycle for the fast seasonal drip ER-G1. This pattern is as clearly present in the first year of ${ }^{14} \mathrm{C}$ analysis for drip site ER76 , but the seasonality is not visible in the second year. In both $\delta^{13} \mathrm{C}$ drip water records, no relation to soil air and soil water $\delta^{13} \mathrm{C}$ was observed. Furthermore, there is no clear relation observed between ${ }^{14} \mathrm{C}$ activity and $\delta^{13} \mathrm{C}$ in drip water of both drips due to several processes that change the isotopic composition of the water and which are not necessarily constant over subannual timescales. The observed changes in both $\mathrm{C}$ isotopic compositions are attributed to $\mathrm{C}$ exchange processes and to small variations in the degree of the open versus closed carbonate dissolution. However, the expected variations in $\delta^{13} \mathrm{C}$ are masked by other processes, such as isotopic fractionation due to degassing in the cave or in hydrological pathways, which cause larger changes in $\delta^{13} \mathrm{C}$ than in ${ }^{14} \mathrm{C}$ activity. The relative change in $\delta^{13} \mathrm{C}$ due to fractionation is in the range of $10 \%$ by accounting the conversion of $\mathrm{HCO}_{3}{ }^{-}$to gaseous $\mathrm{CO}_{2}$. This value is relatively large compared to the differences of the end members contributing to the total $\mathrm{C}$ in the solution (about $-25 \%$ of soil air and $\sim 0 \%$ of marine-derived carbonate). For the ${ }^{14} \mathrm{C}$ activity, the difference between soil air ( 100-110 pMC) and host-rock carbonate $(0 \mathrm{pMC})$ is much larger than changes induced by fractionation effects $(\sim 2 \mathrm{pMC}$ for the conversion of $\mathrm{HCO}_{3}{ }^{-}$to gaseous $\mathrm{CO}_{2}$ ).

$\mathrm{C}$ isotopic composition of ER-G1 drip water is largely controlled by variations in the C exchange processes between solution and host-rock carbonate and in the second order by the degree of open versus closed calcite dissolution. At this drip location, the infiltration-dependent residence time of the water in the aquifer controls $\mathrm{C}$ exchange processes. A negative correlation between ${ }^{14} \mathrm{C}$ activity and drip rate is then established, because drip rate also depends on infiltration. The negative correlation is observed under a certain drip rate threshold. Above that threshold of $\sim 15 \mathrm{~mL} / \mathrm{min}$, a positive (non-linear) relationship between ${ }^{14} \mathrm{C}$ activity and drip rate is observed.

The calcite dissolution of location ER-76 seems to occur under more closed conditions compared to ER-G1. Furthermore, $\mathrm{C}$ isotope exchange and additional mixing of water within the aquifer also play an important role. Additionally, degassing affects the $\mathrm{C}$ isotope composition due to the low drip rate and long sampling time. This all leads to a change in the $\mathrm{C}$ isotopic composition compared to the ER- 
G1 location. Hence, no correlation between drip rate and ${ }^{14} \mathrm{C}$ is observed for ER-76. Although results and interpretation are conclusive, further monitoring is necessary to support our findings.

\section{ACKNOWLEDGMENTS}

This work was funded by DFG Research Group 668 (DAPHNE). We thank Göran Skog at Lund AMS facility for ${ }^{14} \mathrm{C}$ analyses. The authors are also very grateful to I J Fairchild for a critical review of the first draft of the manuscript. We would like to thank 2 anonymous reviewers, who helped to improve our manuscript.

\section{REFERENCES}

Andrews JA, Harrison KG, Matamala R, Schlesinger WH. 1999. Separation of root respiration from total soil respiration using carbon-13 labelling during FreeAir Carbon Dioxide Enrichment (FACE). Soil Science Society of America Journal 63:1429-35.

Avanzini M, Frisia S, van den Driessche K, Keppens E. 1997. A dinosaur tracksite in an Early Liassic tidal flat in northern Italy: paleoenvironmental reconstruction from sedimentology and geochemistry. PALAIOS 12(6):538-51.

Baldini JUL, McDermott F, Hoffmann DL, Richards DA, Clipson N. 2008. Very high-frequency and seasonal cave atmosphere $\mathrm{pCO}_{2}$ variability: implications for stalagmite growth and oxygen isotope-based paleoclimate records. Earth and Planetary Science Letters 272(1-2):118-29.

Borsato A. 1997. Dripwater monitoring at Grotta di Ernesto (NE Italy): a contribution to the understanding of karst hydrology and the kinetics of carbonate dissolution. In: Proceedings of the 12th International Congress of Speleology. Volume 2. p 57-60.

Borsato A, Frisia S, Fairchild IJ, Somogyi A, Susini J. 2007. Trace element distribution in annual stalagmite laminae mapped by micrometer-resolution X-ray fluorescence: implications for incorporation of environmentally significant species. Geochimica et Cosmochimica Acta 71(6):1494-512.

Bowling DR, McDowell NG, Bond BJ, Law BE, Ehleringer JR. 2002. ${ }^{13} \mathrm{C}$ content of ecosystem respiration is linked to precipitation and vapour pressure deficit. Oecologia 131(1):113-24.

Cerling TE. 1984. The stable isotopic composition of modern soil carbonate and its relationships to climate. Earth and Planetary Science Letters 71(2):229-40.

Clark ID, Fritz P. 1997. Environmental Isotopes in Hydrogeology. Boca Raton: CRC Press. 328 p.

Criss R, Davisson L, Surbeck H, Winston W. 2007. Isotopic methods. In: Goldscheider N, Drew D, editors. Methods in Karst Hydrogeology. London: Taylor and Francis. p 123-45.

Deines P. 1980. The isotopic composition of reduced organic soil. In: Fritz P, Fontes JC, editors. Handbook of Isotope Geochemistry, 1 The Terrestrial Environment. Amsterdam: Elsevier. p 329-406.

Dörr H, Münnich KO. 1986. Annual variations of the ${ }^{14} \mathrm{C}$ content. Radiocarbon 28(2A):338-45.
Dreybrodt W. 1988. Processes in Karst Systems - Physics, Chemistry and Geology. Berlin: Springer Verlag. $288 \mathrm{p}$.

Dulinski M, Rozanski K. 1990. Formation of ${ }^{13} \mathrm{C} /{ }^{12} \mathrm{C}$ isotope ratios in speleothems: a semi-dynamic model. Radiocarbon 32(1):7-16.

Ekblad A, Högberg P. 2001. Natural abundance of ${ }^{13} \mathrm{C}$ in $\mathrm{CO}_{2}$ respired from forest soils reveals speed of link between tree photosynthesis and root respiration. Oecologia 127:305-8.

Fairchild IJ, Bradby L, Sharp M, Tison J-L. 1994. Hydrochemistry of carbonate terrains in alpine glacial settings. Earth Surface Processes and Landforms 19:3354.

Fairchild IJ, Borsato A, Tooth AF, Frisia S, Hawkesworth CJ, Huang Y, McDermott F, Spiro B. 2000. Controls on trace element (Sr-Mg) compositions of carbonate cave water: implications for speleothem climatic records. Chemical Geology 166(3-4):255-69.

Fairchild IJ, Tuckwell GW, Baker A, Tooth AF. 2006. Modelling of dripwater hydrology and hydrogeochemistry in a weakly karstified aquifer (Bath, UK): implications for climate change. Journal of Hydrology 321(1-4):213-31.

Fohlmeister J, Kromer B, Mangini A. Forthcoming. The influence of soil organic matter age spectrum on the reconstruction of atmospheric ${ }^{14} \mathrm{C}$ levels via stalagmites. Radiocarbon.

Frisia S, Borsato A, Fairchild IJ, McDermott F. 2000. Calcite fabrics, growth mechanisms, and environments of formation in speleothems from the Italian Alps and south-western Ireland. Journal of Sedimentary Research 70(5):1183-96.

Frisia S, Borsato A, Preto N, McDermott F. 2003. Late Holocene annual growth in three alpine stalagmite records the influence of solar activity and the North Atlantic Oscillation on winter climate. Earth and Planetary Science Letters 216(3):411-24.

Frisia S, Borsato A, Fairchild IJ, Susini S. 2005. Variations in atmospheric sulphate recorded in stalagmites by synchrotron micro-XRF and XANES analyses. Earth and Planetary Science Letters 235(3-4):72940.

Frisia S, Fairchild IJ, Fohlmeister J, Miorandi R, Spötl C, Borsato A. 2010. Carbon mass-balance modelling and carbon isotope exchange processes in dynamic caves. 
Geochimica et Cosmochimica Acta. doi: 10.1016/ j.gca.2010.10.021.

Garrels RM, Christ CL. 1965. Solutions, Minerals and Equilibria. New York: Harper \& Row. 450 p.

Genty D, Massault M. 1997. Bomb ${ }^{14} \mathrm{C}$ recorded in laminated speleothems: calculations of dead carbon proportion. Radiocarbon 39(1):33-48.

Genty D, Massault M. 1999. Carbon transfer dynamics from bomb- ${ }^{14} \mathrm{C}$ and $\delta^{13} \mathrm{C}$ time series of a laminated stalagmite from SW France-modelling and comparison with other stalagmite records. Geochimica et Cosmochimica Acta 63(10):1537-48.

Genty D, Vokal B, Obelic B, Massault M. 1998. Bomb ${ }^{14} \mathrm{C}$ time history recorded in two modern stalagmites-importance for soil organic matter dynamics and bomb ${ }^{14} \mathrm{C}$ distribution over continents. Earth and Planetary Science Letters 160(3-4):795-809.

Gorczyca Z, Rozanski K, Kuc T, Michalec B. 2003. Seasonal variability of the soil $\mathrm{CO}_{2}$ flux and its isotopic composition in southern Poland. Nukleonika 48(4): 187-96.

Hendy CH. 1970. The use of ${ }^{14} \mathrm{C}$ in the study of cave processes. In: Olsson I, editor. Radiocarbon Variations and Absolute Chronology. New York: Wiley. p 41943.

Hendy CH. 1971. The isotopic geochemistry of speleothems. I. The calculation of the effects of different modes of formation on the isotopic composition of speleothems and their applicability as palaeoclimatic indicators. Geochimica et Cosmochimica Acta 35(8): 801-24.

Huang YM, Fairchild IJ, Borsato A, Frisia S, Cassidy NJ, McDermott F, Hawkesworth CJ. 2001. Seasonal variations in $\mathrm{Sr}, \mathrm{Mg}$ and $\mathrm{P}$ in modern speleothems (Grotta di Ernesto, Italy). Chemical Geology 175(3-4):429 48.

Larssen T, Jiling X, Vogt RD, Seip HM, Bohan L, Dianwu Z. 1998. Studies of soils, soil water and stream water at a small catchment near Guiyang, China. $\mathrm{Wa}$ ter, Air, and Soil Pollution 101(1-4):137-62.

McDermott F. 2004. Palaeo-climate reconstruction from stable isotope variations in speleothems: a review. Quaternary Science Reviews 23(7-8):901-18.

McDermott F, Frisia S, Huang Y, Longinelli A, Spiro B, Heaton THE, Hawkesworth CJ, Borsato A, Keppens E, Fairchild IJ, van der Borg K, Verheyden S, Selmo EM. 1999. Holocene climate variability in Europe: evidence from $\delta^{18} \mathrm{O}$, textural and extension-rate variations in three speleothems. Quaternary Science Reviews 18(8-9):1021-38.

Merkli C, Sartori G, Mirabella A, Egli M, Mancabelli A, Plötze M. 2009. The soils in the Brenta region: chemical and mineralogical characteristics and their relation to landscape evolution. Studi Tridentino di Scienze Naturali Acta Geologica 22:7-22.

Miorandi R, Borsato A, Frisia S, Fairchild IJ, Richter D. 2010. Epikarst hydrology and implications for stalagmite capture of climate changes at Grotta di Ernesto
(NE Italy): results from long-term monitoring. Hydrological Processes 24(21):3101-14.

Mook WG, de Vries JJ. 2000. Environmental Isotopes in the Hydrological Cycle Principles and Applications Volume I: Introduction - Theory, Methods, Review. Vienna: IAEA.

Nielsen AE, Toft JM. 1984. Electrolyte crystal growth kinetics. Journal of Crystal Growth 67(2):278-88.

Plummer LN, Parkhurst DL, Kosiur DR. 1975. MIX2, a Computer Program for Modelling Chemical Reactions in Natural Waters. US Geological Survey, Water Resources Investigations Report $61.75 \mathrm{p}$.

Salièges JF, Fontes JC. 1984. Essai de détermination expérimentale du fractionnement des isotopes ${ }^{13} \mathrm{C}$ et ${ }^{14} \mathrm{C}$ du carbone au cours de processus naturels. International Journal of Applied Radiation and Isotopes 35(1): $55-62$.

Salomons W, Mook WG. 1986. Isotope geochemistry of carbonates in the weathering zone. In: Fritz P, Fontes JC, editors. Handbook of Isotope Geochemistry, 1 The Terrestrial Environment. Amsterdam: Elsevier. p 23970.

Schlesinger WH. 1977. Carbon balance in terrestrial detritus. Annual Review of Ecology and Systematics 8: 51-81.

Spötl C. 2004. A simple method of soil gas stable carbon isotope analysis. Rapid Communications in Mass Spectrometry 18(11):1239-42.

Spötl C. 2005. A robust and fast method of sampling and analysis of $\delta^{13} \mathrm{C}$ of dissolved inorganic carbon in ground waters. Isotopes in Environmental and Health Studies 41(3):217-21.

Spötl C, Fairchild IJ, Tooth AF. 2005. Cave air control on dripwater geochemistry, Obir Caves (Austria): implications for speleothem deposition in dynamically ventilated caves. Geochimica et Cosmochimica Acta 69(10):2451-68.

Steinmann K, Siegwolf RTW, Saurer M, Körner C. 2004. Carbon fluxes to the soil in a mature temperate forest assessed by ${ }^{13} \mathrm{C}$ isotope tracing. Oecologia 141(3): 489-501.

Tegen I, Dörr H. 1996. ${ }^{14} \mathrm{C}$ measurements of soil organic matter, soil $\mathrm{CO}_{2}$ and dissolved organic carbon. Radiocarbon 38(2):247-51.

Thornthwaite CW. 1948. An approach toward a rational classification of climate. Geographical Review 38(1): 55-94.

Trumbore SE. 2000. Age of soil organic matter and soil respiration: radiocarbon constraints on belowground C dynamics. Ecological Applications 10(2):399-411.

Wendt I, Stahl W, Geyh MA, Fauth F. 1967. Model experiments for ${ }^{14} \mathrm{C}$ water-age determinations. In: Isotopes in Hydrology, Proceedings of the IAEA. p 32137.

Wigley TML. 1975. Carbon-14 dating of groundwater from closed and open systems. Water Resources Research 11(2):324-8. 